\title{
Successful restoration of function of frozen and thawed isolated rat hearts
}

\author{
Amir Elami, MD, ${ }^{a, *}$ Zohar Gavish, MSc, ${ }^{\mathrm{b}, *}$ Amit Korach, MD, ${ }^{a}$ Esther Houminer, MA, ${ }^{a}$ Aviva Schneider, MSc, ${ }^{a}$ \\ Herzl Schwalb, PhD, and Amir Arav, DVM, PhD ${ }^{\mathrm{b}}$
}

$\mathcal{B}$ Supplemental material is available online.
From The Department of Cardiothoracic Surgery and the Joseph Lunenfeld Cardiac Surgery Research Center, ${ }^{\mathrm{a}}$ HadassahHebrew University Medical Center, Jerusalem; and Core Dynamics Ltd ${ }^{\mathrm{b}}$ Ness Ziona, Israel.

This work was supported in part by a grant donated by Michael Foley, New York, NY.

* Zohar Gavish and Amir Elami contributed equally to this work.

Received for publication March 20, 2007; revisions received July 29, 2007; accepted for publication Aug 2, 2007.

Address for reprints: Amir Elami, MD, Department of Cardiothoracic Surgery, Hadassah-Hebrew University Medical Center, PO 12000, Jerusalem 91120, Israel (E-mail: amirel@ekmd.huji.ac.il).

J Thorac Cardiovasc Surg 2008;135:666-72 $0022-5223 / \$ 34.00$

Copyright (C) 2008 by The American Association for Thoracic Surgery

doi:10.1016/j.jtcvs.2007.08.056
Objective: Long-term organ preservation for transplantation may allow optimal donor-recipient matching with potential reduction in the incidence and severity of rejection. Complete cessation of metabolism may be obtained by freezing. Previous attempts to freeze intact mammalian hearts were limited to $-3.6^{\circ} \mathrm{C}$, restricting tissue ice content to $34 \%$. We hypothesized that our method will allow recovery of function of the intact rat heart after freezing to $-8^{\circ} \mathrm{C}$, a temperature at which most of the tissue water is frozen.

Methods: Isolated rat hearts were attached to a Langendorff apparatus. After normothermic perfusion, cold cardioplegia was induced followed by perfusion with a cryoprotecting agent. Hearts were than frozen to $-8^{\circ} \mathrm{C}$ ( $45 \pm 8$ minutes), thawed, and reperfused (60 minutes).

Results: All frozen and thawed hearts regained normal electric activity. At $-8^{\circ} \mathrm{C}$, ice content was $64.36 \% \pm 13 \%$. The use of $10 \%$ ethylene glycol for cryoprotection $(\mathrm{n}=$ 13 ) resulted in recovery (mean \pm standard deviation) of $49.7 \% \pm 21.8 \%$ of $+\mathrm{dP} / \mathrm{dt}$, $48.0 \% \pm 23.5 \%$ of $-\mathrm{dP} / \mathrm{dt}, 65.2 \% \pm 30.8 \%$ of coronary flow, and $50.4 \% \pm 23.9 \%$ of left ventricular developed pressure. Hearts in this group $(n=4)$ maintained $81.3 \% \pm$ $10 \%$ viability compared with $69.3 \% \pm 14 \%$ (not significant) in control hearts kept at $0^{\circ} \mathrm{C}$ for the same duration. Energy stores, represented by adenosine triphosphate and phosphocreatine, were depleted to $12.2 \pm 6.1 \mu \mathrm{mol} / \mathrm{g}$ dry weight and $22.5 \pm 6.4$ $\mu \mathrm{mol} / \mathrm{g}$ dry weight, respectively, compared with $19.0 \pm 2.5 \mu \mathrm{mol} / \mathrm{g}$ dry weight and $36.6 \pm 3.0 \mu \mathrm{mol} / \mathrm{g}$ dry weight, respectively $(P<.05)$ in the control hearts. The integrity of muscle fibers and intracellular organelles after thawing and reperfusion was demonstrated by electron microscopy.

Conclusion: We demonstrate for the first time the feasibility of functional recovery after freezing and thawing of the isolated rat heart while maintaining structural integrity and viability.

$\mathrm{L}$ ong-term organ preservation without tissue injury may open new horizons in the treatment of important medical problems. Hypothermic organ preservation for transplantation restricts the ischemic time for donor hearts or lungs to only a few hours, precluding donor-recipient matching between remote places. Because of these time constraints, matching is limited to only blood type and body size. The prolongation of organ preservation may allow optimal immunologic matching of the donor with potential recipients. This in turn could lead to reduction of the incidence of rejection and the intensity of immunosuppression needed after transplantation and, ultimately, lower costs of care with improved results.

Hypothermia, used for thoracic organs preservation, does not stop metabolism, but it slows biochemical reactions and decreases the rate at which intracellular enzymes degrade essential cellular components necessary for organ viability. Total cessation of metabolism could be obtained by freezing of these organs. However, previous attempts to freeze intact mammalian hearts were limited to a minimal temperature of $-3.6^{\circ} \mathrm{C}$ to restrict tissue ice content to less than $40 \%$, resulting in supercooling of 

Abbreviations and Acronyms
$\mathrm{EG}=$ ethylene glycol
$\mathrm{HR}=$ heart rate
$\mathrm{KH}=$ Krebs-Henseleit
LVDP $=$ left ventricular developed pressure
MTT = methylthiazoldiphenyl-tetrazolium bromide
UW = University of Wisconsin

the rest of tissue water and avoiding the destructive effects of release of latent heat and induction of isothermal period characterizing the initiation of the freezing process. The recovery of cardiac output in these hearts after 6 hours was $50 \% .^{1,2}$ By using a novel freezing method and microsurgical techniques, we recently demonstrated the ability to preserve hormonal activity and ovulation after autotransplantation of frozenthawed ovaries in sheep. ${ }^{3,4}$ In the present study, using a modification of our freezing method, we demonstrate the potential for functional recovery and preservation of structural integrity and energy stores and maintenance of tissue viability of isolated rat hearts subjected to freezing to $-8^{\circ} \mathrm{C}$ with tissue ice content of more than $60 \%$.

\section{Materials and Methods Solutions}

Modified Krebs-Henseleit (KH) solution was prepared daily according to Neely and Rovetto, ${ }^{5}$ containing the following: 118 $\mathrm{mmol} / \mathrm{L} \mathrm{NaCl}, 4.9 \mathrm{mmol} / \mathrm{L} \mathrm{KCl}, 1.2 \mathrm{mmol} / \mathrm{L} \mathrm{MgSO}_{4}, 1.2 \mathrm{mmol} / \mathrm{L}$ $\mathrm{KH}_{2} \mathrm{PO}_{4}, 25 \mathrm{mmol} / \mathrm{L} \mathrm{NaHCO}, 11.1 \mathrm{mmol} / \mathrm{L}$ glucose, and 2.5 $\mathrm{mmol} / \mathrm{L} \mathrm{CaCl}_{2}$.

University of Wisconsin (UW) ViaSpan was obtained from Bristol-Myers-Squibb Company, Princeton, NJ.

Ethylene glycol (EG) (Sigma-Aldrich Israel Ltd, Rehovot, Israel) was added to the UW solution to obtain a final concentration of $5 \%$ or $10 \%$ in the UWEG solution delivered to the hearts before freezing.

For the methyl-thiazol-diphenyl-tetrazolium (MTT) assay, glucose phosphate-buffered saline was prepared daily in distilled water and contained $136.9 \mathrm{mmol} / \mathrm{L} \mathrm{NaCl}, 2.68 \mathrm{mmol} / \mathrm{L} \mathrm{KCl}, 8.10 \mathrm{mmol} / \mathrm{L}$ $\mathrm{Na}_{2} \mathrm{HPO}_{4}, 1.53 \mathrm{mmol} / \mathrm{L} \mathrm{KH}_{2} \mathrm{PO}_{4}, 0.5 \mathrm{mmol} / \mathrm{L} \mathrm{MgCl} 2,0.9 \mathrm{mmol} / \mathrm{L}$ $\mathrm{CaCl}_{2}$, and $5.55 \mathrm{mmol} / \mathrm{L}$ glucose $(\mathrm{pH} 7.45)$.

\section{Isolated Heart Perfusion}

Male Sprague Dawley rats weighing $280 \pm 20 \mathrm{~g}$ were used for the experiments. Handling of the animals was in accord with the Guide for the Care and Use of Laboratory Animals published by the U.S. National Institutes of Health (Publication No. 85-23, revised 1996). The animals were intraperitoneally injected with sodium heparin (500 U) and 30 minutes later were anesthetized with pentobarbital (30 mg/animal). The hearts were immediately removed and placed in heparinized ice-cold saline solution. The aorta was cannulated to a Langendorff perfusion apparatus, and the pulmonary artery was cut open to provide drainage.

Retrograde aortic perfusion was maintained with a modified $\mathrm{KH}$ solution and aerated with a mixture of $95 \%(\mathrm{v} / \mathrm{v})$ oxygen and $5 \%$ (v/v) carbon dioxide. The initial aortic perfusion ( $\mathrm{KH}$ solution) was maintained at $37^{\circ} \mathrm{C}$ and a pressure of $90 \mathrm{~cm} \mathrm{H}_{2} \mathrm{O}$.

\section{Hemodynamic Measurements}

Hemodynamic parameters were monitored using a latex balloontipped catheter inserted through an incision in the left atrium and advanced through the mitral valve into the left ventricle and connected to a pressure transducer placed at equivalent height to the heart and a recording system (PowerLab, ADInstruments, Bella Vista NSW, Australia). The balloon was inflated and equilibrated to give an end-diastolic pressure of $0 \mathrm{~mm} \mathrm{Hg}$. Left ventricular systolic and diastolic pressures and time derivatives of pressure were measured during contraction $(+\mathrm{dP} / \mathrm{dt})$ and relaxation $(-\mathrm{dP} / \mathrm{dt})$. Left ventricular developed pressure (LVDP) was calculated as the difference between the systolic and diastolic pressures. The work index of the heart (LVDP $\times$ heart rate $[\mathrm{HR}])$ was derived from the product of LVDP and HR. Coronary flow rate was measured by collecting the effluent drained through the pulmonary artery during precooling/ freezing and during reperfusion.

\section{Assessment of Ethylene Glycol Toxicity}

A series of experiments was performed to assess the toxicity of the different EG concentrations (see Appendix E1 for results).

\section{Assessment of Tissue Ice Content}

Tissue ice content was determined by calorimetry as previously described. , $^{6,7}$ Immediately after reaching the desired temperature, the heart was transferred to a glass vacuum-isolated calorimeter. The change in water temperature after the introduction of the frozen heart was digitally recorded using a thermocouple connected to a digital thermometer. The ice content of the frozen heart was calculated using the following equation:

$$
\mathrm{Wi}=\frac{\mathrm{F}(\mathrm{Ww})(\mathrm{Sw})(\mathrm{Ti}-\mathrm{Tf})+(\mathrm{Ts}-\mathrm{Tf})[(\mathrm{Wd})(\mathrm{Sd})+(\mathrm{Ws})(\mathrm{Sw})]}{(\mathrm{Ts}-\mathrm{Tf})(\mathrm{Sw})+\mathrm{Q}+\mathrm{Si}(\mathrm{Mp}-\mathrm{Ts})+\mathrm{Sw}(\mathrm{Tf}-\mathrm{Mp})}
$$

Where: $\mathrm{F}=$ calorimeter constant $=0.65, \mathrm{Mp}=$ melting point of tissue fluids $\left({ }^{\circ} \mathrm{C}\right)=-0.8, \mathrm{Q}=$ heat of fusion of water $(79.7 \mathrm{cal} / \mathrm{g} \times$ $\left.{ }^{\circ} \mathrm{C}\right), \mathrm{Sd}=$ specific heat of the dry tissue $\left(0.3 \mathrm{cal} / \mathrm{g} \times{ }^{\circ} \mathrm{C}\right), \mathrm{Si}=$ specific heat of ice $\left(0.5 \mathrm{cal} / \mathrm{g} \times{ }^{\circ} \mathrm{C}\right), \mathrm{Sw}=$ specific heat of water at $20^{\circ} \mathrm{C}$ $\left(0.9988 \mathrm{cal} / \mathrm{g} \times{ }^{\circ} \mathrm{C}\right), \mathrm{Tf}=$ final temperature of the water in the calorimeter $\left({ }^{\circ} \mathrm{C}\right), \mathrm{Ti}=$ initial temperature of the water in the calorimeter $\left({ }^{\circ} \mathrm{C}\right), \mathrm{Ts}=$ temperature of the tissue, $\mathrm{Wd}=$ weight of tissue dry mass $(\mathrm{g}), \mathrm{Wi}=$ weight of ice in tissue $(\mathrm{g})$, Ws = weight of water in tissue $(\mathrm{g})$, and $\mathrm{Ww}=$ weight of water in the calorimeter $(\mathrm{g})$. Sixteen hearts were used to determine ice content at $0^{\circ} \mathrm{C}(2),-3.5^{\circ} \mathrm{C}$ (6), $-8^{\circ} \mathrm{C}(6)$, and $-20^{\circ} \mathrm{C}$ (2). The tissue ice content was expressed as a percentage of total tissue water.

\section{Experimental Protocol}

Hearts were subjected to 20 minutes of perfusion $\left(\mathrm{KH}, 37^{\circ} \mathrm{C}\right)$ for basic hemodynamic measurements. The latex balloon was removed, and a thermocouple was inserted into the left ventricle through the left atrium to monitor endocardial temperature. Cold cardioplegia $\left(4^{\circ} \mathrm{C}\right)$ was perfused (via the side arm) for 1 minute $(10 \mathrm{~mL} \mathrm{UW})$, followed by $10 \mathrm{~mL}$ perfusion of either UW + EG 5\% (UW EG 5\%, group $1, \mathrm{n}=8$ ) or UW + EG $10 \%$ (UW EG $10 \%$, group $2, \mathrm{n}=$ 13) for 3 minutes. The heart was disconnected from the perfusion 
system and transferred to the freezing apparatus. After reaching the desired endocardial temperature of $-8^{\circ} \mathrm{C}$ (range $-7^{\circ} \mathrm{C}$ to $-10^{\circ} \mathrm{C}, 45$ \pm 8 minutes), the frozen hearts were thawed in saline solution at $37^{\circ} \mathrm{C}$ for 20 to 30 seconds and reattached to the perfusion system for 60 minutes of normothermic reperfusion with $\mathrm{KH}$. The latex balloon was reinserted into the left ventricle and reinflated to identical volume as during the preischemic period. Hemodynamic measurements at the end of the normothermic reperfusion were compared with the basic measurements taken before freezing, each heart serving as a control for itself. Four hearts perfused for 20 minutes at normothermia were arrested with UW solution, kept ischemic while immersed in UW solution $\left(0^{\circ} \mathrm{C}, 50\right.$ minutes $)$, and reperfused with $\mathrm{KH}$ solution for 60 minutes (control).

After conclusion of the reperfusion procedures, while the hearts were still beating, left ventricular slices ( 1 cubic $\mathrm{mm}$ ) were taken for electron microscopy. Slices from these hearts were removed for viability test and analyzed by methythiazoldiphenyl-tetrazolium bromide (MTT, Sigma Chemical Co, St Louis, Mo). ${ }^{8}$ The beating hearts were than rapidly frozen, and adenosine triphosphate and phosphocreatine were extracted with perchloric acid and determined enzymatically. 9,10

The baseline values for high-energy phosphate content and tissue viability were also determined in a group of rat hearts $(n=6)$ not exposed to ischemia and reperfusion (preischemia control).

\section{Freezing Process}

Freezing was performed using a novel freezing device (Core Dynamics Ltd, Ness Ziona, Israel) based on directional freezing technology (patent pending). In brief, the device is built with temperature domains within two 70-mm brass blocks. The freezing device was precooled to $0^{\circ} \mathrm{C}$ and remained at that temperature for at least 20 minutes before onset of the freezing process. A thermocouple was inserted into the left ventricle through the incision in the left atrium to monitor myocardial temperature. The heart was placed at the center of the freezing chamber and immersed in UWEG solution. Initial cooling at a rate of $-0.5^{\circ} \mathrm{C} / \mathrm{min}$ was controlled by setting the temperature of the brass blocks to $-5^{\circ} \mathrm{C}$, followed by reduction of the temperature of the device to $-10^{\circ} \mathrm{C}$ to increase the cooling rate to $-1.0^{\circ} \mathrm{C} / \mathrm{min}$. The final myocardial temperature of $-8^{\circ} \mathrm{C}$ was accomplished by cooling the device to as low as $-15^{\circ} \mathrm{C}$. Thawing was performed by plunging the freezing chamber into a saline bath at $37^{\circ} \mathrm{C}$ for $25 \pm 5$ seconds until the heart separated from the surrounding ice.

To ascertain that freezing was uniform and transmural, and to exclude the possibility that the myocardium itself was only supercooled, a separate experiment was performed with simultaneous, direct measurement of the intramyocardial temperature and the temperature in the left atrium (Figure 1).

\section{Adenosine Triphosphate and Phosphocreatine Determination}

At the end of reperfusion, the hearts were rapidly frozen with stainless-steel blocks precooled in liquid nitrogen. Perchloric acid extracts were prepared from tissue samples according to the method of Lowry and Passonneau. ${ }^{9}$ Adenosine triphosphate and phosphocreatine levels were assessed by the enzymatic assay of Lampecht and Stein, ${ }^{10}$ and expressed as micromoles per gram of dry weight of myocardial tissue (dried at $90^{\circ} \mathrm{C}$ for 24 hours).

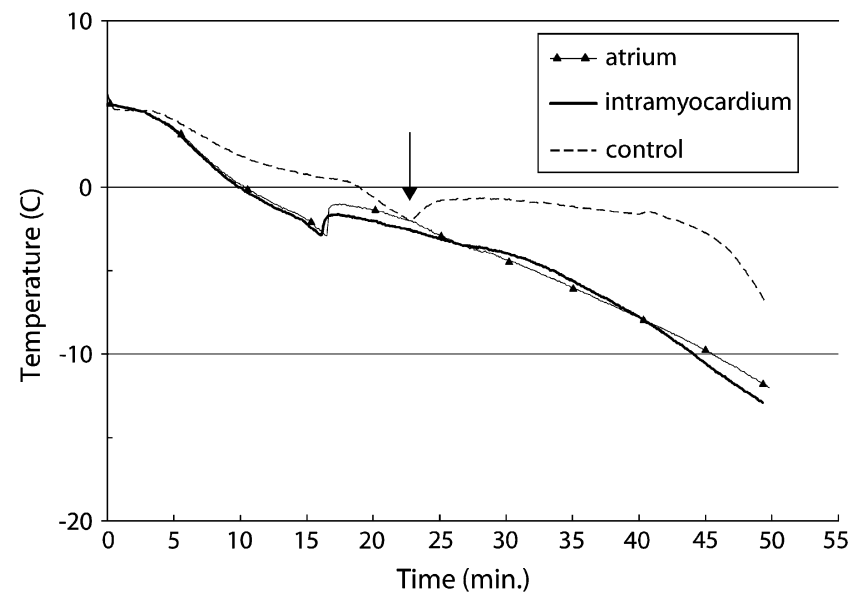

Figure 1. Freezing curves of the rat hearts. The line representing the temperature curve during conventional freezing of a rat heart (control) demonstrates a long isothermal period. The arrow points to where the release of latent heat at sub-zero temperature is evident. By using our novel freezing method in a separate experiment, intramyocardial temperature was measured simultaneously with atrial temperature to verify uniform transmural cooling and freezing.

\section{Assessment of Tissue Viability by MTT}

At the end of the experimental protocol, tissue viability was determined by MTT staining: reduction of 3-[4,5 dimethylthiazol-2yl]2.5 diphenyltetrazolium bromide to blue formazan by mitochondrial dehydrogenases. The intensity of MTT staining in the myocardial slices is correlated with the viability of the tissue. ${ }^{8}$

Ventricular slices of 1-mm thickness were incubated in $20 \mathrm{~mL}$ of glucose phosphate-buffered saline containing MTT $(0.5 \mathrm{mg} / \mathrm{mL})$ at $37^{\circ} \mathrm{C}$ for 90 minutes under a mild flow of oxygen. The slices were then transferred to a small test tube containing $3 \mathrm{~mL}$ of phosphate-buffered saline, which was shaken for 1 minute to remove excess dye. The slices were transferred into tubes with dimethyl sulfoxide and homogenized for 10 seconds using a HG-300 Homogenizer (Hsiangtai Machinery Industry Co, Ltd, Taiwan). Extraction of the formazan dye into dimethyl sulfoxide was done with vigorous shaking for 1 hour at $37^{\circ} \mathrm{C}$. The homogenate was centrifuged for 10 minutes at $4000 \mathrm{~g}$, and the colored supernatant was measured spectrophotometrically at $500 \mathrm{~nm}$. The slices were dried in a $90^{\circ} \mathrm{C}$ oven for 24 hours, and the results were expressed as optical density per milligram of dry weight of myocardial tissue. Tissue viability was expressed as the ratio between the optical density of treated hearts to that of its aerobic controls ( 8 control hearts perfused with $\mathrm{KH}$ for 20 minutes $=100 \%$ viability), normalized to the dry weight of the myocardial tissue.

\section{Electron Microscopy}

The heart slices were fixed and processed for electron microscopy as described by Gilead and colleagues. ${ }^{11}$

\section{Statistical Analysis}

Hemodynamic and metabolic parameters are expressed as means \pm standard deviation. The statistical significance of the differences 
TABLE 1. Hemodynamic recovery $(\%)$ after freezing $\left(-8^{\circ} \mathrm{C}, 48 \pm 5\right.$ minutes), thawing, and normothermic reperfusion (60 minutes)

\begin{tabular}{|c|c|c|c|c|}
\hline \multirow[b]{3}{*}{ Preservation conditions } & \multicolumn{4}{|c|}{ Preischemic hemodynamic parameters and recovery $(\%)$ after freezing to $-8^{\circ} \mathrm{C}$ and thawing $(\mathrm{M} \pm \mathrm{SD})$} \\
\hline & \multicolumn{2}{|c|}{ Group 1 UW + EG 5\% (n= 8) } & \multicolumn{2}{|c|}{ Group 2 UW + EG 10\% (n = 13) } \\
\hline & Preischemia & Reperfusion (\%) & Preischemia & Reperfusion (\%) \\
\hline$+\mathrm{dP} / \mathrm{dt}$ & $2247 \pm 365$ & $26.8 \pm 14.5$ & $2287 \pm 512$ & $49.7 \pm 21.8^{*}$ \\
\hline$-\mathrm{dP} / \mathrm{dt}$ & $1934 \pm 385$ & $24.9 \pm 13.6$ & $1939 \pm 436$ & $48.0 \pm 23.5^{*}$ \\
\hline CF & $13.6 \pm 2.6$ & $81.0 \pm 20.3$ & $13.0 \pm 2.8$ & $65.2 \pm 30.8$ \\
\hline HR & $268 \pm 28$ & $92.3 \pm 16.5$ & $264 \pm 41$ & $88.6 \pm 14.2$ \\
\hline LVDP & $123 \pm 11.5$ & $27.4 \pm 14.6$ & $126 \pm 26$ & $50.4 \pm 23.9$ \\
\hline LVDP $\times \mathrm{HR}$ & $33,327 \pm 5293$ & $25.6 \pm 14.1$ & $32,902 \pm 7063$ & $43.3 \pm 20.0$ \\
\hline
\end{tabular}

$S D$, Standard deviation; $E G$, ethylene glycol; $U W$, University of Wisconsin; $C F$, coronary flow; $H R$, heart rate; $L V D P$, left ventricular developed pressure. Preischemic hemodynamic units: $\mathrm{dP} / \mathrm{dt}=\mathrm{mm} \mathrm{Hg} / \mathrm{sec} ; \mathrm{CF}=\mathrm{mL} / \mathrm{min} ; \mathrm{HR}=$ beats/min; $\mathrm{LVDP}=\mathrm{mm} \mathrm{Hg} ; \mathrm{LVDP} \times \mathrm{HR}=\mathrm{mm} \mathrm{Hg} \times$ beats/min. ${ }^{*} P<.05 \mathrm{versus}$ group 1 .

between samples was evaluated using 1-way analysis of variance followed by the Mann-Whitney rank test for post hoc analysis.

\section{Results}

All hearts in the 2 study groups regained contractile function after freezing and thawing. The recovery of hemodynamic parameters is presented as the percentage of the original function after harvest and stabilization for the 2 study groups (Table 1). The recovery of parameters representing systolic and diastolic function $(+\mathrm{dP} / \mathrm{dt}$ and $-\mathrm{dP} / \mathrm{dt})$ was significantly better $(P<.05)$ among hearts frozen with 10\% EG (group 2) than among the hearts frozen with 5\% EG (Table 1). The spontaneous beating rate (HR) of the frozen and thawed hearts recovered to high levels of $88.6 \% \pm 14.2 \%$. Control hearts $(\mathrm{n}=4)$, not subjected to freezing and kept at $0^{\circ} \mathrm{C}$ for 50 minutes, recovered $64.4 \% \pm 13.3 \%$ of their preische$\mathrm{mic}+\mathrm{dP} / \mathrm{dt}, 62.3 \% \pm 15.0 \%$ of $-\mathrm{dP} / \mathrm{dt}, 87.0 \% \pm 16.8 \%$ of coronary flow, $111.9 \% \pm 20.6 \%$ of HR, $61.1 \% \pm 10.5 \%$ of LVDP, and $70.0 \% \pm 23.4 \%$ of the preischemic LVDP $\times$ HR.

Figure 2 demonstrates a representative freezing and thawing experiment. A regular (no arrhythmia) beat-to-beat trace of the systolic and diastolic pressures is presented during the preischemic perfusion and the post-freezing reperfusion.

The uniformity of our freezing process across the ventricular wall is depicted in Figure 1. No temperature gradients were detected between the myocardium and the endocardium, excluding the possibility of super-cooling rather than freezing of the myocardium. Figure 1 indicates (in group 2 hearts, frozen with $10 \%$ EG using our special device) the avoidance of a harmful isothermal period secondary to the release of latent heat, resulting in freezing at a predetermined cooling rate, in contrast with a super-cooling phenomenon shown during conventional freezing (control).

The decreased energetic reserve of the frozen and thawed hearts of group 2 (UW + EG 10\%), as reflected by adenosine triphosphate and phosphocreatine levels, is presented in Table 2. Both adenosine triphosphate and phosphocreatinine were significantly lower than during the preischemic period, but when compared with hearts that were not subjected to EG and freezing and were preserved at $0^{\circ} \mathrm{C}$, only phosphocreatine was significantly lower $(P<.05$; Table 2$)$.

The tissue viability of hearts of group $2(\mathrm{n}=4)$, as demonstrated by the MTT test, is shown in Table 2. Good viability was found for the frozen, thawed, and reperfused hearts of group $2(81.3 \% \pm 10 \%)$; although the viability was better than that of the control group, preserved at $0^{\circ} \mathrm{C}(69.3 \% \pm$ $14 \%$ ), the difference was not significant (Table 2). A small sample $(n=2)$ of group 1 hearts confirmed that not only the hemodynamic results were inferior after the freezing and thawing process (Table 1) but also the protection as reflected by the biochemical analysis (Table 2).

The integrity of the muscle fibers and intracellular organelles after thawing and reperfusion is demonstrated by electron microscopy in Figure 3, which demonstrates regular arrays of myofibrils, divided into sarcomeres. It shows numerous intact mitochondria between the myofibrils and the presence of T-tubules $(\mathrm{T})$ that penetrate into the muscle at the level of the Z-bands. We did not find any precipitations of $\mathrm{Ca}^{2+}$ in the mitochondria, as was found for hearts subjected to normothermic ischemia and reperfusion.

The cooling of hearts perfused with UWEG $10 \%$ to $-3.5^{\circ} \mathrm{C}$ resulted in only partial freezing (super-cooling) of the tissue water rendering more than $80 \%$ of the water unfrozen. At $-8^{\circ} \mathrm{C}$, with the use of our novel freezing method, the hearts reached an ice content of $64.36 \% \pm$ $13.18 \%$ (Table 3).

\section{Discussion}

Previous studies in cryopreservation of the explanted rat heart attempted to mimic the adaptive strategies for natural freeze tolerance that had been described in amphibians and reptiles. ${ }^{12}$ Slow cooling $\left(0.18^{\circ} \mathrm{C} / \mathrm{min}\right)$ was limited to a temperature that would restrict tissue ice formation to less than $40 \%{ }^{1}$ This level of freezing was believed to be the highest level that could be tolerated by the rat heart. ${ }^{13}$ By using various cryoprotective agents to supplement the cardioplegic 


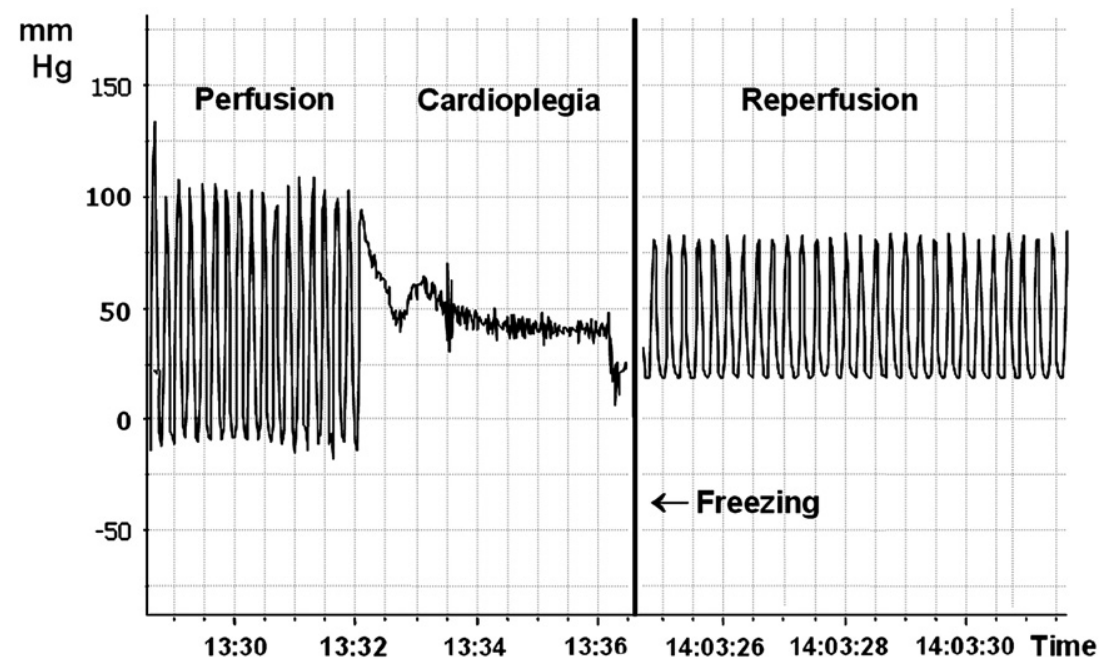

Figure 2. Representative freezing and thawing (UW + EG 10\%) experiment. Real-time progress of the experiment is presented along the $X$ axis, and the intraventricular pressure (systolic and diastolic, $\mathrm{mm} \mathrm{Hg}$ ) is shown on the $\mathrm{Y}$ axis. The perpendicular dark line at the center of the chart represents the freezing of the heart (-8 $\mathrm{C}, 48$ minutes). A regular (no arrhythmia) beat-to-beat trace of the systolic and diastolic pressures during preischemic perfusion and post-freezing reperfusion is presented on the chart.

solution, different thawing rates, and an isolated working heart model, these researchers demonstrated up to $60 \%$ recovery of function as measured by cardiac output. ${ }^{2}$ Their target temperature was, however, $-3.4^{\circ} \mathrm{C}$, which resulted in freezing of only $34 \%$ of the tissue water. ${ }^{2}$

We demonstrate for the first time that recovery of function is possible after freezing of the rat heart to $-8^{\circ} \mathrm{C}$ (or even $-10^{\circ} \mathrm{C}$ ), which resulted in more than $60 \%$ ice content. On the basis of our previous experience with ovarian freezing, we elected to use EG as a cryoprotective agent and found that adding $10 \%$ EG to our cardioplegic solution (UW) yielded the best recovery after freezing to $-8^{\circ} \mathrm{C}$.

The recovery of function after freezing and thawing was probably the result of the unique freezing method used in our experiment. The process of ice formation begins with the creation of an ice nucleus (ie, 1 ice crystal). Along with the decrease in temperature, more and more ice crystals join this first ice focus, leading to ongoing growth of a large ice front. This procedure is complete when all of the water in the sample to be frozen is turned into ice. Our method is based on 2 principles. It allows controlled direction of the ice front from epicardium to endocardium, thereby maintaining 1 direction of freezing in a precise cooling rate, which avoids the formation of intracellular ice. Second, we believe that efficient release of latent heat during the freezing process is of paramount importance. The use of conventional freezing is associated with a long and potentially destructive isothermal period resulting from the release of the latent heat. In the present study, we used 2 foci of simultaneous nucleation because our preliminary experience indicated that this was preferable to a single focus of nucleation (data not shown). Our hypothesis regarding this phenomenon is that by using 2 foci simultaneously we rendered the evacuation of latent heat more efficient, thereby shortening the duration of the isothermal period.

As noted earlier, the spontaneous beating rate (HR) of the frozen and thawed hearts recovered to high levels of approximately $90 \%$. This is important, because it means that the pacemaker and conductance system of the heart are practically unaffected by the freezing and thawing process. Energy stores of the frozen and thawed hearts were significantly depleted compared with the control hearts. This could be due to the toxic effect of EG during the period between induction of cardioplegic arrest and reaching the frozen state, or during the time between thawing and complete rinsing of the EG on reperfusion. It should be noted, however, that although energy stores were significantly depleted, viability was maintained $(81.3 \% \pm 10 \%$ by MTT assay), indicating intactness of cellular membranes with preservation of the nucleotides nicotinamide adenine dinucleotide/reduced nicotinamide adenine

TABLE 2. Energy stores and viability before ischemia and after cooling or freezing followed by normothermic reperfusion

\begin{tabular}{|c|c|c|c|c|}
\hline & $\begin{array}{c}\text { Group } 1 \text { UW }+ \text { EG 5\%, } \\
-8^{\circ} \mathrm{C}(\mathrm{n}=2)\end{array}$ & $\begin{array}{c}\text { Group } 2 \text { UW + EG } 10 \% \\
-8^{\circ} \mathrm{C}(\mathrm{n}=4)\end{array}$ & $\begin{array}{l}\text { Control UW, } \\
0^{\circ} C(n=4)\end{array}$ & $\begin{array}{l}\text { Preischemic Control, } \\
\quad 37^{\circ} \mathrm{C}(\mathrm{n}=6)\end{array}$ \\
\hline ATP & $3.9,5.4$ & $12.2 \pm 6.1$ & $19.0 \pm 2.5$ & $21.3 \pm 5.1$ \\
\hline Phosphocreatine & $12.7,15.6$ & $22.5 \pm 6.4^{*}$ & $36.6 \pm 3.0$ & $32.8 \pm 7.9$ \\
\hline Viability (\%) & $76 \%, 76 \%$ & $81.3 \% \pm 10 \%$ & $69.3 \% \pm 14 \%$ & $100 \%$ \\
\hline
\end{tabular}

UW, University of Wisconsin; $E G$, ethylene glycol; ATP, adenosine triphosphate. ATP and phosphocreatine ( $\mu$ mol/g dry weight); viability (MTT assay) was measured as described in "Materials and Methods." ${ }^{*} P<.05$ versus control. The difference between group 2 and the preischemic control was significant for all parameters. 


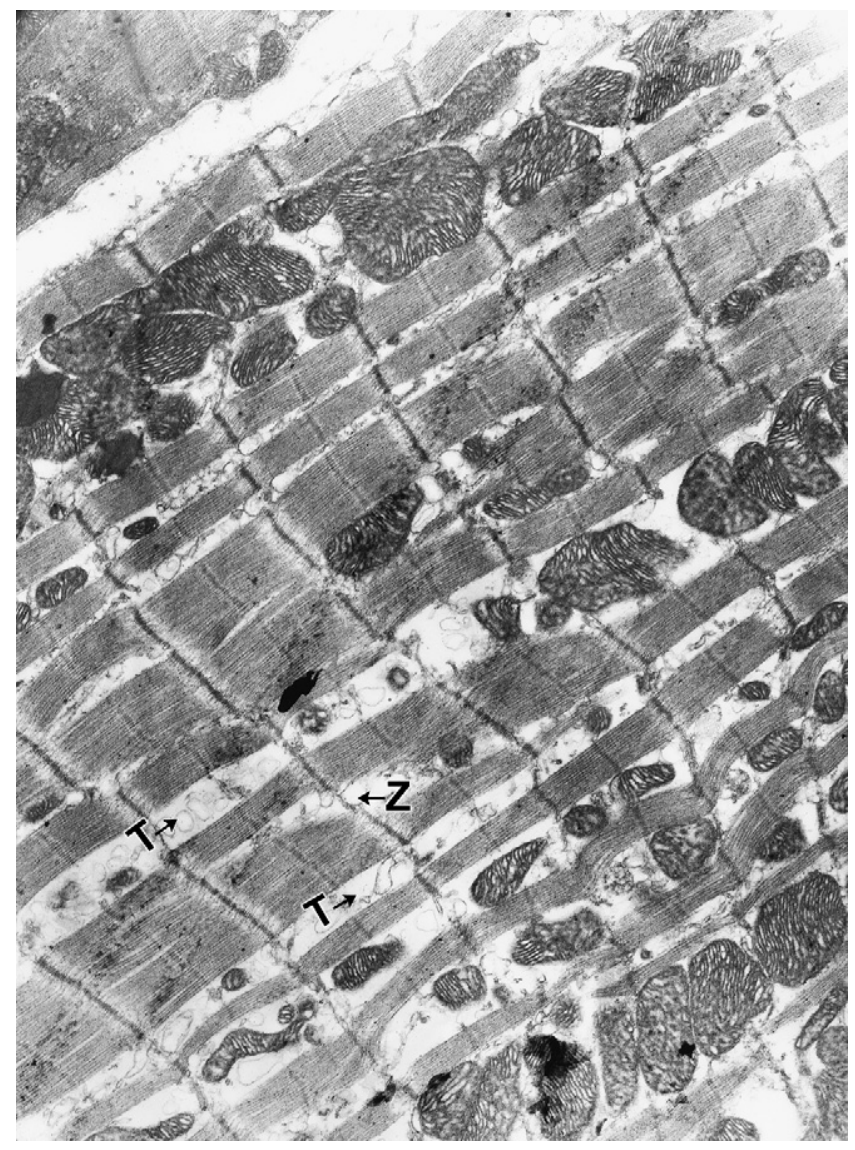

Figure 3. Longitudinal section of left ventricular muscle after freezing in UW and $10 \%$ EG, thawing, and normothermic reperfusion. The section is showing regular arrays of myofibrils, divided into sarcomeres. Note the presence of numerous intact mitochondria between the myofibrils and the presence of T-tubules $(T)$, which penetrate into the muscle at the level of the Z-bands $(\times 21,000)$.

dinucleotide necessary for the MTT reaction and oxidative phosphorylation.

Nevertheless, although the initial results are encouraging, we observed a significant decay of function after reperfusion of the thawed hearts. Possible ways to improve the preservation of function after freezing and thawing should address the toxic effects of EG. A lower concentration of EG may be less toxic to the tissue; however, the protection afforded by this concentration while freezing to complete icing of tissue water is insufficient. Therefore, a better freezing solution should be designed to reduce toxicity but at the same time allow enough freezing protection.

The rapid thawing rate was implicated as responsible for the reduction of viability and function in some models. ${ }^{14-16}$ However, cell swelling subsequent to rapid thawing did not occur in the defrosted hearts, according to electron microscopy findings. Initial reperfusion with UW solution rather
TABLE 3. Ice content of isolated rat hearts perfused with University of Wisconsin organ preservation solution + ethylene glycol $10 \%$ at various freezing temperatures using our freezing method

\begin{tabular}{lcc}
\hline Tissue temperature $\left({ }^{\circ} \mathbf{C}\right)$ & $\mathbf{n}$ & Ice content $(\%) \pm \mathbf{S D}$ \\
\hline 0 & 2 & $2.64 \pm 3.29$ \\
-3.5 & 6 & $15.28 \pm 5.62$ \\
-8 & 6 & $64.36 \pm 13.18$ \\
-20 & 2 & $78.74 \pm 9.60$ \\
\hline
\end{tabular}

$S D$, Standard deviation.

than with $\mathrm{KH}$ solution may be tested in an attempt to minimize the potential for rapid dilution of the intra- and extracellular solutes.

In our freezing process, ice crystals were formed only in the extracellular space and within the blood vessels. Endothelial damage secondary to the formation of these crystals within the coronary arteries could account for uneven reperfusion and loss of function. Cryopreservation of canine coronary arteries to $-75^{\circ} \mathrm{C}$ in the presence of dimethyl sulfoxide and fetal calf serum for 7 days resulted in a loss of only $15 \%$ to $20 \%$ of the endothelium-dependent vasodilatory response. ${ }^{17}$ However, quantitative assessment of human coronary and mesenteric arteries after cryopreservation to $-196^{\circ} \mathrm{C}$ using dimethyl sulfoxide with or without fetal calf serum as a cryoprotective agent revealed marked endothelial denudation and diminished contractile (62\% of control) and endothelium-dependent relaxant $(26 \%-38 \%)$ responses of these arteries. ${ }^{18}$ Such damage could have accounted for the failure of some of the ovaries retransplanted after freezing in our previous experience ${ }^{3,4}$ and for the marked depletion of energy stores in underperfused zones in the frozen and thawed hearts in the present study. The morphologic and functional recovery of coronary arteries frozen according to our protocol will be the focus of a separate series of experiments.

\section{Conclusions}

We demonstrated the feasibility of functional recovery after freezing and thawing of the heart. In addition, we demonstrated structural integrity and energy production during the reperfusion. Additional studies are needed for decreasing the toxicity of the preservation solution and improving the functional recovery.

\section{References}

1. Wang T, Banker MC, Claydon M, Hicks GL Jr, Layne JR Jr. Freezing preservation of the mammalian cardiac explant V. Cryoprotection by ethanol. Cryobiology. 1992;29:470-7.

2. Zhu Q, Layne JR Jr, Claydon M, Hicks GL Jr, Wang T. Freezing preservation of the mammalian cardiac explant VI. Effect of thawing rate on functional recovery. Cryobiology. 1992;29:478-84.

3. Revel A, Elami A, Bor A, Natan Y, Yavin S, Arav A. Whole sheep ovary cryopreservation and transplantation. Fertil Steril. 2004;82:1714-5.

4. Arav A, Revel A, Nathan Y, Bor A, Gacitua H, Yavin S, et al. Oocyte recovery, embryo development and ovarian function after 
cryopreservation and transplantation of whole sheep ovary. Hum Reprod. 2005;20:3554-9.

5. Neely JR, Rovetto MJ. Techniques for perfusing isolated rat hearts. Methods Enzymol. 1975;9:43-60.

6. Wang TC, Connery CP, Batty PR, Hicks GL Jr, DeWeese JA, Layne JR Jr. Freezing preservation of adult mammalian heart at high subzero temperatures. Cryobiology. 1991;28:171-6.

7. Voituron Y, Eugene M, Barre H. Survival and metabolic responses to freezing by the water frog (Rana ridibunda). J Exp Zoolog A Comp Exp Biol. 2003;299:118-26.

8. Ghosh S, Standen NB, Galinanes M. Preconditioning the human myocardium by simulated ischemia: studies on the early and delayed protection. Cardiovasc Res. 2000;45:339-50.

9. Lowry OH, Passonneau JV. A Flexible System of Enzymatic Analysis. London: Academic Press; 1972:123.

10. Lamprecht W, Stein P, Heinz F, Weisser H. Creative phosphate. In: Bergmeyer HU, ed. Methods of Enzymatic Analysis. New York, NY: Academic Press; 1974;4:1777-81.

11. Gilead L, Rahamim E, Ziv I, Or R, Razin E. Cultured human bone marrow-derived mast cells, their similarities to cultured murine E-mast cells. Immunology. 1988;63:669-75.
12. Storey KB. Life in a frozen state: adaptive strategies for natural freeze tolerance in amphibians and reptiles. Am J Physiol. 1990;258:R559-68.

13. Banker MC, Layne JR Jr, Hicks GL Jr, Wang T. Freezing preservation of the mammalian cardiac explant II. Comparing the protective effect of glycerol and polyethylene glycol. Cryobiology. 1992;29:87-94.

14. Pegg DE, Jacobsen IA, Diaper MP, Foreman J. The effect of cooling and warming rate on cortical cell function of glycerolized rabbit kidneys. Cryobiology. 1984;21:529-35.

15. Fiser PS, Fairfull RW, Marcus GJ. The effect of thawing velocity on survival and acrosomal integrity of ram spermatozoa frozen at optimal and suboptimal rates in straws. Cryobiology. 1986;23:141-9.

16. Layne JR Jr, First MC. Resumption of physiological functions in the wood frogs (Rana sylvatica) following freezing. Am J Physiol. 1991; 261:R134-7.

17. Ku DD, Willis WL, Caulfield JB. Retention of endothelium-dependent vasodilatory responses in canine coronary arteries following cryopreservation. Cryobiology. 1990;27:511-20.

18. Muller-Schweinitzer E, Mihatsch MJ, Schilling M, Haefeli WE. Functional recovery of human mesenteric and coronary arteries after cryopreservation at -196 degrees $\mathrm{C}$ in a serum-free medium. $J$ Vasc Surg. 1997;25:743-50. 


\section{Appendix E1}

Effect of EG toxicity ( $5 \%$ and $10 \%$ EG). The hearts were perfused for 20 minutes at $37^{\circ} \mathrm{C}(\mathrm{KH})$ and then arrested with UW solution (10 mL, $4^{\circ} \mathrm{C}$ for 1 minute), followed by $10 \mathrm{~mL}$ of cold $\left(4^{\circ} \mathrm{C}\right) \mathrm{UW}$ + EG $5 \%$ (control EG 5\%, $\mathrm{n}=6$ ) or UW + EG 10\% (control EG $10 \%, \mathrm{n}=8$ ) administered for 3 minutes. The hearts were then immersed in UW solution at $4^{\circ} \mathrm{C}$ to complete 25 minutes of ischemia since the end of initial perfusion period. This was followed by 60 minutes of normothermic reperfusion $(\mathrm{KH})$. Hearts perfused for 20 minutes at $37^{\circ} \mathrm{C}(\mathrm{KH})$ and then arrested with UW solution (10 $\mathrm{mL}, 4^{\circ} \mathrm{C}$ for 1 minute) and immersed in UW solution to complete 25 minutes of ischemia followed by normothermic reperfusion for 60 minutes served as the control for the solution effect (control EG 0\%, $\mathrm{n}=6$ ).

Although the addition of $10 \%$ EG to the UW solution yielded a significantly improved functional recovery of the frozen and thawed hearts, this concentration of EG was more toxic to the hearts kept ischemic at $4^{\circ} \mathrm{C}$ (toxicity is temperature dependent). This was mainly evident for the $-\mathrm{dP} / \mathrm{dt}$ and coronary flow (Table E1). The recovery of the spontaneous beating (HR) was less affected by the toxicity of EG.
TABLE E1. Toxicity effect of ethylene glycol on hemodynamic recovery $(\%)$ after cold ischemia $(25$ minutes, $4^{\circ} \mathrm{C}$ ) and normothermic reperfusion

\begin{tabular}{lccc}
\hline & \multicolumn{3}{c}{ Hemodynamic recovery (M \pm SD \%) } \\
\cline { 2 - 4 } & $\begin{array}{c}\text { Control EG 5\% } \\
(\mathbf{n}=\mathbf{6})\end{array}$ & $\begin{array}{c}\text { Control EG 10\% } \\
(\mathbf{n}=\mathbf{8})\end{array}$ & $\begin{array}{c}\text { Control EG 0\% } \\
(\mathbf{n}=\mathbf{6})\end{array}$ \\
\hline$+\mathrm{dP} / \mathrm{dt}$ & $83.9 \pm 14.5$ & $66.4 \pm 15.1$ & $91.7 \pm 22.4$ \\
$-\mathrm{dP} / \mathrm{dt}$ & $83.2 \pm 10.1$ & $65.5 \pm 16.9^{*} \dagger$ & $88.0 \pm 19.2$ \\
Coronary flow & $91.5 \pm 32.4$ & $65.5 \pm 15.3^{*}$ & $92.4 \pm 28.0$ \\
$\mathrm{HR}$ & $102.3 \pm 12.0$ & $92.9 \pm 14.9$ & $90.0 \pm 15.5$ \\
LVDP & $83.0 \pm 15.6$ & $65.3 \pm 14.1$ & $90.8 \pm 21.0$ \\
LVDP $\times$ HR & $84.9 \pm 18.0$ & $61.5 \pm 20.7$ & $82.3 \pm 25.4$
\end{tabular}

$S D$, Standard deviation; $E G$, ethylene glycol; $H R$, heart rate; $L V D P$, left ventricular developed pressure. ${ }^{*} P<.05$ versus control. $\dagger P<.05$ versus group 1 . 